\title{
RZECZ O DAMACH, RYCERZACH I BALWANACH... SEMANTYKA 'SPOJRZENIA' W POWIEŚCI WITKACEGO 622 UPADKI BUNGA, CZYLI DEMONICZNA KOBIETA
}

Językowy obraz świata - pisze Jerzy Bartmiński - „jest zawartą w języku, różnie zwerbalizowaną interpretacją rzeczywistości dającą się ująć w postaci zespołu sądów o świecie. Mogą to być sądy "utrwalone”, czyli mające oparcie w samej materii języka, a więc w gramatyce, słownictwie, w kliszowych tekstach (np. przysłowiach), a także sądy presuponowane, tj. implikowane przez formy językowe, utrwalone na poziomie wiedzy społecznej, przekonań, mitów i rytuałów" (Bartmiński, 2009: 12). Kategoria językowego obrazu świata, jak zauważa Ryszard Tokarski, nie tylko uwidacznia obraz rzeczywistości pozajęzykowej zawarty w języku, ale niesie też za sobą pewne wartościowanie - mniej zauważalne, ale i bardziej „sztywne” oraz mocniej zakorzenione w języku. Pisze on: „Szczególnie interesujące dla odtworzenie niektórych aspektów językowego obrazu świata są jednak te kategorie, które da się ująć w ramach binarnej opozycji „swój” - „obcy”. „Swój” - a zatem lepszy, wartościowszy, w przeciwieństwie do "obcego", który jest gorszy, mniej wartościowy, niższy w hierarchii" (Tokarski, 1999: 80). Na tej podstawie wyznacza on pięć podstawowych kategorii związanych z wartościowaniem, które konstytuują językowy obraz świata w polszczyźnie. Są to: ksenofobia, antropocentryzm, świadomość wyższości kultury europejskiej, chrystianizm oraz etos rycerski. I choć sam autor zaznacza, iż etos rycerski jako składnik językowego obrazu świata polszczyzny jest aspektem najbardziej hipotetycznym (por. Tokarski, 1999: 81), to on będzie wyznaczał w niniejszej analizie oś konstrukcyjną poszukiwanej semantyki 'spojrzenia' w powieści Witkacego 622 upadki Bunga czyli Demoniczna kobieta. 
Najbardziej znaną i cenioną na gruncie polskim pracą poświęconą temu co nazywamy etosem rycerskim jest książka Marii Ossowskiej Ethos rycerski $i$ jego odmiany. Nie jest naszym celem streszczanie tego powszechnie znanego dzieła, lecz zwrócenie uwagi na pewne zasadnicze dla podjętej analizy jego aspekty. Pierwszym z nich jest samo pojęcie etosu, które, jak podkreśla autorka, niesie za sobą pewne wzorce zachowań. Etos wiąże się więc z pojęciem wzoru - ideału oraz jego naśladownictwem. Pisze ona, iż z samego etosu „wyłania się zupełnie określony obraz, który będzie można przyjąć jak typ idealny” (Ossowska, 1986: 21). Wzory, które zawsze wartościowane są pozytywnie, nie podlegają też weryfikacji prawdziwościowej - zawsze pozostają one tylko pewnymi modelami oczekiwanymi czy pożądanymi, które częstokroć chcemy uważać za prawdziwe i rzeczywiste. Są one jednak głęboko zakorzenione w kulturze i ich struktura z trudem ulega zmianom. Drugą kwestią zasadniczą dla dalszych rozważań jest fakt, iż na etos rycerski składają się dwie główne płaszczyzny działania mężczyzny - rycerza wyznaczane przez domeny walki i miłości. „Bić się i kochać” - reasumuje Maria Ossowska - to hasło rycerza” (Ossowska, 1986: 80). I jak wraz z przemianami społeczno-ekonomicznymi kultury Zachodu schemat walki z konieczności podlega zmianom, przekształcając wzorzec rycerza - wojownika we wzorzec gentelmana, tak schemat miłości pozostaje odpornym na działanie czasu. Na doniosłość wzorca miłości rycerskiej w konstytuowaniu się semantyki miłości zwraca również uwagę Krystyna Straczewska, która strukturę tego uczucia opiera na trzech zasadniczych typach działań, nazywanych "działaniami motywowanymi przez miłość” (por. Straczewska, 1975: 11). Wyróżnia ona trzy typy idealne miłości oparte na działaniach miłosnych Chrystusa, Tristana oraz Don Juana, które też, jej zdaniem, kształtują szereg wzorów zachowań miłosnych w kulturze europejskiej. I gdy Chrystus w pełni uosabia miłosierdzie, a Don Juan symbolizuje nieokiełznaną i zasadniczo uproszczoną namiętność, to właśnie Tristan - rycerz łączy w sobie obie te siły. Zaproponowany tu podział w pełni inkluduje wyróżniany przez tradycję filozofii Zachodu rozdział między miłością jako uczuciem - Agape, a miłością jako pożądaniem - Eros. Jednakże, jak zauważa Gernot Böhme, obok tych zwyczajowo wyróżnianych wzorów miłości, funkcjonuje trzeci - wzór miłości rycerskiej zrodzonej w kręgach dworskich we wczesnym średniowieczu, którą nazywa minne. „Minne, jak tłumaczy sam autor, to miłujące uwielbienie przez młodego rycerza jego damy, z reguły zamężnej kobiety, często żony jego suwerena" (Böhme, 1998: 91). Dalej konklu- 
duje on, iż miłość rycerska - minne, w znaczący sposób ukształtowała wzorzec zachowań rycerskich, zrodziła wiele ważnych wartości do dziś obowiązujących w kulturze europejskiej i kształtujących normy zachowań społecznych. To także ona wykształciła tak ważne w naszej kulturze pojęcie rycerskości. Jednakże, co silnie na każdym kroku podkreśla Gernot Böhme - istotą i elementem różnicującym ten wzorzec od pozostałych jest idea 'spojrzenia'. Pisze on: „Spojrzenie to pierwsze i zasadnicze doświadczenie minne. Spojrzeniem jest się ugodzonym w serce, co sprawia, że istota taka niejako z konieczności staje się istotą kochającą" (Böhme, 1998: 92). W ten sposób dochodzimy do sedna naszych rozważań - semantyki 'spojrzenia', którą nazywamy tak na wzór Semantyki miłości Niclasa Luhmanna, sugerując tym samym, że będzie miała ona szerszy wymiar społeczno-kulturowy. Takie rozumienie implikuje też samo pojęcie etosu. Terminem semantyka 'spojrzenia' obejmuję zatem szereg działań zorientowanych na miłość, skonceptualizowanych w wymiarze wzroku, a ukonstytuowanych we wzorze miłości rycerskiej. Wyłaniającą się na przestrzeni powieści Witkacego semantykę ‘spojrzenia' pragnę ograniczyć do analizy materiału mieszczącego się w kategorii językowego obrazu kobiety, zawężając tym samym zakres opisywanego problemu do aspektów mieszczących się $\mathrm{w}$ przytoczonym kręgu zainteresowań badawczych, nie będących jednak bezpośrednim przedmiotem rozważań.

Według Uniwersalnego słownika języka polskiego 'spojrzenie' to „a) rzecz. od spojrzeć”; „b) wzrok w chwili patrzenia, wzrok, oczy zwrócone, skierowane na kogoś, na coś”; "c) sposób widzenia i oceny czegoś". Z kolei, jak czytamy w Innym słowniku języka polskiego 'spojrzenie' "1. To rzeczownik od "spojrzeć". 2. Słowa spojrzenie używamy $2.1 \mathrm{z}$ czasownikami wyrażającymi ruch lub powodowanie ruchu, aby powiedzieć na co kierują się czyjeś oczy. [...] 2.2 z innymi wyrazami, zwłaszcza z przymiotnikami, aby powiedzieć, jakie cechy, zamiary lub pragnienia są w czyichś oczach. [...] 3. Mówimy o spojrzeniu, gdy oczy tej osoby kierują się na kogoś lub na coś. [...]. 4. Określenie spojrzenie na coś to sposób widzenia i oceny tego." Z definicji tych wyłania się pewien model pojęcia ‘spojrzenie', na podstawie którego możemy wyodrębnić określone domeny jego profilowania w języku. Po pierwsze spojrzenie to działanie; działanie o charakterze częstokroć chwilowym, wymagające jednak istnienia drugiego podmiotu bądź przedmiotu, a także pewnego rodzaju interakcji z nim; po drugie - spojrzenie niesie za sobą szereg uczuć i postaw podmiotu "patrzącego"; i w końcu - po trzecie spojrzenie ma charak- 
ter wartościujący, oceniający. Interpretację tę zdaje się potwierdzać Iwona Nowakowska-Kempna, która analizując sposoby konceptualizacji uczuć w języku polskim, zwraca uwagę także na wymiar wzroku. Będąc związanym na stałe z ludzkim spojrzeniem na rzeczywistość, konceptualizuje on w sobie bogactwo uczuć zakodowane w języku. Swoje rozważania puentuje ona próbą sformułowania definicji kognitywnej, opartej na następującym wyidealizowanym modelu poznawczym (IMC):

\section{OCZY TO POJEMNIK NA UCZUCIA \\ OCZY TO ZWIERCIADŁO DUSZY \\ ROBIĆ COŚ OCZAMI TO UCZUCIE \\ OCZY TO PRZEDMIOT, Z KTÓRYM MOŻNA COŚ ZROBIĆ (Nowakowska- -Kempna, 2005: 146).}

Rozumienie 'spojrzenia' jako działania implikowane jest także przez motywowanie tej formy rzeczownikowej przez czasownik 'spojrzeć'. Czasownik ten pozostaje $\mathrm{w}$ bliskim związku znaczeniowym $\mathrm{z}$ formami 'patrzeć' i 'widzieć'. Wszystkie bowiem te trzy formy odnoszą się do wzroku - zmysłu postrzegania świata fizycznego. Jednakże pomimo zbliżonych sfer denotacyjnych, każdy z tych leksemów niesie za sobą nieco odmienne konotacje. Te subtelne różnice możemy dostrzec $\mathrm{w}$ samych definicjach wspomnianych pojęć. I tak wg Innego Stownika Języka Polskiego: „Jeśli spojrzeliśmy na jakąś osobę lub rzecz, to skierowaliśmy wzrok w jej stronę i przez chwilę popatrzyliśmy na nią"; "Jeśli patrzymy na jakąś osobę, rzecz lub jakieś zdarzenie albo, rzadziej, jeśli patrzymy się na nie, to kierujemy na nie wzrok", a z kolei "Jeśli widzimy jakąś osobę lub rzecz, to patrząc zauważamy ją." Różnice wyłaniające się z konfrontacji tych pojęć sytuują 'spojrzenie', pomiędzy 'patrzeniem' i 'widzeniem'. I kiedy to pierwsze jest czynnością, działaniem opartym na zdolności fizjologicznej operowania zmysłem wzroku skoncentrowanym na samym podmiocie patrzenia, to to ostatnie zakłada istnienie obiektu przez wzrok postrzeganego, a tym samym implikuje pewną wiedzę podmiotu o nim. 'Spojrzenie', sytuując się między tymi oboma pojęciami, będzie więc działaniem podmiotu za pomocą wzroku zorientowanym na wiedzę o obiekcie swego działania, jednakże o charakterze chwilowym, niestałym, a więc zakładającym niemożność poznania istoty obiektu, lecz uchwycenie jedynie jego cech fizycznych, zewnętrznych, powierzchownych.

Rozumienie 'spojrzenia' jako działania w pełni wpisuje się we wzorzec miłości minne. Gernot Böhme następująco tłumaczy schemat jej 
funkcjonowania: „W pierwszej fazie jest minne w istocie czymś jednostronnym, mianowicie miłującym uwielbieniem rycerza dla jego damy. Na miłość tę można odpowiedzieć taką samą miarą; dzieje się to wtedy, gdy dama „uzna” rycerza. Jego dążenia do realizacji własnej miłości kierują się właśnie ku takiemu uznaniu. Uzyskawszy je rycerz będzie pod znakiem swojej damy - z reguły nosił jej barwę na kopii czy na hełmie - dokonywać bohaterskich czynów. W ogóle wszystko, co czyni, czyni dla swej damy. Żyje dla niej w jej spojrzeniu. Dla niej walczy w turniejach i jeździ za granicę, lecz cokolwiek robi, musi się jakoś jej objawić. Widzialność jest sposobem jego egzystencji" (Böhme, 1998: 93). Realizację tego schematu na łamach powieści Witkacego w pełni odnajdujemy w wątku miłości głównego bohatera - Bunga do wielkiej sławy śpiewaczki operowej Akne. A, jak podkreśla sam autor, jest to Wielka Miłość - przez wielkie W i wielkie $M$. Wyłania się z tego obraz uczucia oparty na uwielbieniu i adoracji młodego, niedoświadczonego jeszcze mężczyzny, dla dojrzałej, doświadczonej życiowo (i przez życie) oraz zamężnej kobiety. Istota tej miłości zawiera się w idealizacji obrazu kobiety w oczach obserwującego - a więc miłującego ją z daleka, rycerza. Sam wizerunek kobiety zasadza się na czysto zmysłowym postrzeganiu wyidealizowanego obiektu pragnień. Dlatego też bohater Witkacego w pierwszej fazie swej miłości spogląda na wybrankę swego serca z daleka, obserwuje ją, patrzy na nią jedynie: zajęty tylko obserwacja jej twarzy $i$ całej postaci (Witkacy: 89); od czasu do czasu patrzył nieśmiało na Akne i zachwyt jego potegowat się coraz bardziej (Witkacy: 91); widział ja z profilu (Witkacy: 91); przy kolacji Akne siedziała prawie naprzeciw niego i teraz mógt się jej napatrzeć do woli (Witkacy: 90). To spoglądanie na kobietę, a właściwie jej oglądanie, z czasem nabiera na intensywności: $z$ głupkowatym podziwem wpatrywał się (Witkacy: 89); patrzył na nia, nie mogąc ukryć swego zachwytu (Witkacy: 113); patrzył na niq z zachwytem (Witkacy: 240); patrzył na niq zupetnie już zbaraniały ze zdziwienia (Witkacy: 111). Patrzenie to $\mathrm{w}$ początkowym stadium odnosi się jednak tylko i wyłącznie do kobiecej urody - jej zewnętrznego, czysto cielesnego piękna. Bowiem niezaprzeczalnym, a możemy wnosić i że jedynym atutem kobiety wg proponowanego wzorca, jest jej zewnętrzna uroda - postrzegane stereotypowo piękno. Dlatego głównym zadaniem kobiety jest robić, wywierać wrażenie: Muszę pani powiedzieć, że mimika pani i cała jej postać zrobiły na mnie nieskończenie silniejsze wrażenie niż głos (Witkacy: 94); przykuwać wzrok: Nie można było powiedzieć, że jest ładna, a jednak przykuwała wzrok $z$ nieprzeparta siła $i$ notorycz- 
nie piękne koleżanki jej robiły przy niej wrażenie woskowych lalek od fryzjera (Witkacy: 90); po prostu "dobrze” wyglądać: Wyglądała na lat dwadzieścia $i$ była tak piękna, że Bungo uczuł się onieśmielonym (Witkacy: 94). Mężczyzna jest więc tu obserwatorem - tym który patrzy, spogląda, ogląda kobietę, tak iż w jego wyobraźni zaczyna ona tworzyć pełną wizję: Była ona teraz dla niego tylko artystyczna wizją nieznanego mu świata, a jednak czut, że stoi na jakiejś granicy swego istnienia i musi zrobić jakiś decydujący o całym jego życiu wybór (Witkacy: 92). Tak więc fizyczny wygląd kobiety, a właściwie jej niezaprzeczalne, bo wyidealizowane oczyma adoratora, zewnętrzne piękno, przenoszone jest na jej obraz wewnętrzny psychikę i osobowość, tworząc jej całościowy wizerunek. I tak jak u Platona piękno świata tego, było jedynie odbiciem piękna idealnego, tak i piękno kobiecego ciała jest jedynie zaczątkiem przypisywanych jej wartości duchowych: I im więcej się w niq wmyślat, tym wyraźniej występowała mu w wyobraźni jej zewnętrzna postać i tym mniej zrozumiała $i$ bardziej obca wydawała mu się jej psychika (Witkacy: 99); Miał wrażenie, że jest ona tajemniczym, wyższym zjawiskiem, zabłakanym przypadkowo między niegodnych jej ludzi (Witkacy: 100). Bowiem zakochany rycerz widzi w swej oblubienicy, jedynie to, co chce zobaczyć: Akne powiedziała do niego kilka słów bez głębszego znaczenia, jednak było w tym coś niezmiernie miłego i Bungo uczuł od razu, że ma w niej kogoś życzliwego między tylu obcymi, którzy doprowadzali go do rozpaczy (Witkacy: 90); $i$ widział w niej jedynie samotna, opuszczona, biedna dziewczynkę, która fatalizm jej sztuki zmusza do życia z wstrętnymi $i$ wyzyskujacymi ja pod każdym względem ludźmi. Miał wrażenie, że dzieje się jej jakaś potworna krzywda, $i$ jakkolwiek formalnie nie robił żadnego postanowienia w tym kierunku, czut, że musi postepować tak, aby ona odczuła w nim kogoś naprawdę sobie bliskiego i który by mógł być przeciwwaga zalewajacej, według jego mniemania, jej życie pospolitości (Witkacy: 102). Początek miłości - stan zakochania, jest więc tu obrazowany jako uczucie powierzchowne, oparte na wzrokowych jedynie wrażeniach, odpowiadając tym samym zakorzenionym $\mathrm{w}$ języku polskim kolokacjom, frazeologizmom czy przysłowiom oddającym znaczenie 'spojrzenia' w pierwszej fazie miłości: wpaść komuś w oko, miłość wchodzi oczyma, miłość od pierwszego wejrzenia.

Momentem przełomowym w schemacie miłości dworskiej jest chwila, gdy wybranka serca „uznaje” swego adoratora, a więc zaczyna go dostrzegać. Miłość rodzi się tu w spotkaniu się spojrzeń. Jednostronna dotąd adoracji kobiety przez mężczyznę przekształca się w obustronną re- 
lację między podmiotami - relację opartą na wymianie spojrzeń. Wtedy to podziwiający $\mathrm{z}$ daleka jedynie mężczyzna - rycerz pojawia się w polu widzenia wybranki swego serca, a ona zaczyna odpowiadać na jego spojrzenie - własnym: Akne patrzyła na niego także, a dumne i jednocześnie jakby pochłaniajace spojrzenie Bunga jej oczy zdawały się mówić: "Patrz! oto jestem. I ty śmiesz wmawiać w siebie, że nie kochasz? Musisz, czy chcesz, czy nie chcesz, musisz" - zdawaty się szeptać jej usta, rysujące się ciemnokrwawa plama na bladej twarzy. Przez chwile stali tak, jakby gotowi do skoku oboje. Nagle Akne spuściła oczy (Witkacy: 113). W tym sensie „spojrzeniem jest się ugodzonym $\mathrm{w}$ serce, co sprawia, że istota taka niejako z konieczności staje się istotą kochającą" (Böhme, 1998: 92): Myślę tylko to, że pani jest bezwzględnie wszystkim dla mnie, że nic poza pania nie widzę, że słowo "kochać" jest czymś nieskończenie marnym wobec tego, co ja mam dla pani, że jeżeli pani tego zechce, całe moje życie będzie należeć do pani (Witkacy: 115); Patrzyt $w$ jej oczy $i$ kochał ja coraz straszliwiej i głębiej (Witkacy: 125). Od tej pory też doskonała zewnętrznie kochanka nabiera w oczach swego rycerza wymiaru rzeczywistego, a idealizowany dotąd jej obraz zostaje ucieleśniony: Dotąd patrzył na nią tylko jako na zjawisko dziwnej piękności i życie jej wyobrażał sobie jako petne dziwnych wypadków i tajemnic, ale tajemniczość ta była artystycznie określona $i$ artystycznie zrozumiała. Rzeczywistość jej życia $i$ stosunku jej do ludzi nie zastanawiata go i nie niepokoiła wcale. Teraz dopiero, od chwili kiedy ujrzał jakby po raz pierwszy jej łakomie drżace usta $i$ drapieżne, wciagajace zielone oczy, zrozumiał nagle, że Akne żyje naprawdę: ma ciało, które może być pożądanym i może do kogoś należeć, że istnieje jej życie wtasne, rzeczywiste, które musi być zupetnie odrębne od tego, co dotąd znał i pojmował (Witkacy: 99). Obecność cielesna niesie za sobą konieczność obecności psychicznej, posiadania jakiegoś wnętrza - duszy, której obraz uwzniośliłby samą miłość. Pojawia się potrzeba wytworzenia więzi duchowej, pewnej wspólnoty na wyższej płaszczyźnie działania. Dlatego też miłujący pragnie transponować zewnętrzne tylko piękno kobiety na jej właściwości duchowe i intelektualne: $i$ nie opierając się na żadnych konkretnych danych, imputowat sobie jakąś bliżej nieokreślonq wartość, którq mógłby mieć dla Akne. Czuł to bezpośrednio, poza śmiesznościa swoich myśli o jakimś konkretnym przemienieniu jej życia (Witkacy: 104); i wpatrywał się w jej oczy, chcąc zmusić ją do pojęcia wszystkich istotnych kwestii (Witkacy: 139); chciat nadać temu stosunkowi jakąs innq wartość i uczynić paniq Akne znowu godnq wyższych z jego stron uczuć (Witkacy: 235); Jej oczy, fosforyzujace jakimś tajemniczym blaskiem, wpatrzone w Bunga z wyrazem najwyższej miłości, były 
tak cudownie piękne i głębokie, że zdawało się, że lada chwila pani Akne powie coś takiego, od czego wszyscy padna na brzuch i czołgać się będa dla niej w najgłębszej czci i przerażeniu (Witkacy: 135). Dążeniem kochającego jest tu więc zmierzanie do jedności pragnień i chceń, całkowitej jednolitości jestestw - tym, co Krystyna Straczewska nazywa - chceniem tylko tego, co chce wybranka serca. Owo chcenie tylko tego, co chce podmiot kochany, w rzeczywistości jest całkowitą rezygnacją z własnej autonomii. Cielesna tylko atrakcyjność kobiety, jej pozorne, bo zewnętrzne piękno, przy całkowitym braku głębszych wartości, sprawia, iż dążący do osiągnięcia ideału mężczyzna, zatraca sam siebie - staje się tym, który „żyje dla niej w jej spojrzeniu" (Böhme, 1998: 93); dla którego bycie widzianym jest jedynym sposobem egzystencji: Wszystko w nim było bezwzględnq własnościa tej tajemniczej pani, której wcale nie znał i nie pojmowat, a w której rzeczywiste istnienie absolutnie w tej chwili nie wierzyt, mimo że szła o krok przed nim (Witkacy: 116); Kiedy Cię naprawdę kochałem, wtedy mnie nie było wcale (Witkacy: 284).

Stąd też moment uznania rycerza przez damę jego serca - moment spotkania się ich spojrzeń, jest też początkiem walki o zachowanie własnej tożsamości i autonomii. Tym, co potocznie nazywane jest walka ptci, a według Jane Paula Sartre'a stanowi o istocie dialektyki spojrzenia. Jak pisze Grenot Böhme: „Według Sartre’a inny człowiek wynurza się w moim świecie najpierw jako spojrzenie. Mój świat to uporządkowany ze względu na mnie związek rzeczy. Burzy go wyłonienie się kogoś innego, kto wskutek swego pojawienia się wprowadza w ów świat porządek konkurencyjny. [...]. W spojrzeniu kogoś obcego odnajduję sam siebie jako przedmiot.”, a dalej czytamy: „Kochać - to dla Sartre'a w gruncie rzeczy chcieć być kochanym. A to z kolei oznacza chęć wyzwolenia się spod uroku, jaki został na nas rzucony wskutek bycia oglądanym." (Böhme, 1998: 109-110). Dlatego też bohater, który tak zabiega o łaskawe spojrzenie pani swego serca $\mathrm{w}$ chwili, gdy osiągnie swój cel, próbuje wydostać się z obszaru działania jej wzroku: Przypomniał ja sobie z piekielna wyrazistościa i kiedy zamknąt oczy, zdawało mu się, że nachyla się nad nim i patrzy swymi zielonymi oczami, $i$ widzi dokładnie samo najgłębsze dno jego duszy, widzi lepiej od niego to, o czym on dotąd nie miał bladego pojęcia, ale jej własnych myśli nawet w przybliżeniu wyobrazić sobie nie mógł (Witkacy: 129). Staje się on w tym momencie przedmiotem miłości, już nie tym który patrzy, lecz tym na którego się patrzy, który zostaje uprzedmiotowiony przez obce spojrzenie i - jak chce Sartre - żyje tylko w obcym spojrzeniu: Widziat 
przed soba ciagnace ku sobie i poddajace się oczy pani Akne (Witkacy: 132); zielone oczy o silnie rozszerzonych źrenicach i okolone prawie biatymi rzęsami miały $w$ sobie coś drażniącego $i$ wciagającego. Zdawało się, że gdyby chciała, mogłaby wszystko wessać przez oczy i nie robi tego, ponieważ ma za wiele taktu (Witkacy: 90).

W ten sposób działania za pomocą zmysłu wzroku stają się istotnym narzędziem walki o własną tożsamość: co z oczu to $i$ z serca. O tym, że walka ta jest koniecznym elementem schematu miłości wyłaniającego się z etosu rycerskiego, świadczy fakt niemożności jej pełnej realizacji. Miłość ta bowiem z natury jest sprzeczna: rycerz, który nie tylko idealizuje w swych oczach obraz damy swego serca, ale z założenia ma dążyć do całkowitej z nią jedności duchowej z góry skazany jest na niepowodzenie: Nie mógł odwrócić już wypadków, a doświadczenia jego wykazały, że wszelkie dążenie do porozumienia istotnego z paniq Akne pogarszaja tylko sytuację, odbierajac mu tę resztę uroku, który poza swoja konstrukcja fizyczna posiadat (Witkacy: 272); Bungo patrzył na jej twarz cudownie piękna i czysta w blasku księżyca $i$ straszny żal porwat go na myśl, że ona, będąc taka fizycznie, nie może zdobyć się na prawdę w stosunku do niego i uniemożliwia mu prawdziwa dla niej miłość (Witkacy: 237). Jedyną możliwą formą realizacji tej jedności jest akt seksualny. Jednakże jest on tylko chwilowym spełnieniem i sprowadza miłość do pożądania, a jej obiekt w pełni już uprzedmiotawia. Tak więc miłość, która wchodzi przez oczy, to żądza: Patrzyt na nią i tak była wstrętnie piękna, tak diabelsko kuszaca i przewrotna, i tak kłamliwa, że zaczęto go ogarniać straszliwe, ponure, beznadziejne pożadanie (Witkacy: 184); Ty tego drugiego "kochasz", czyli oddajesz mu się (Witkacy: 288).

Asymetryczność, wewnętrzny rozdźwięk między ideałem miłości a niemożnością jego realizacji wydobywa przewijająca się na łamach całej powieści dychotomia zawarta w samym obliczu kobiety - dysharmonia zawarta się między jej oczami i ustami. Ten swoisty dualizm pozwala odkryć istotę miłości minne - jej cielesny, seksualny charakter. Jeżeli za Iwoną Nowakowską-Kempną potraktujemy twarz jako zwierciadło uczuć człowieka, to zauważymy, że „psychiczna strona życia człowieka w sposób oczywisty wyraża się poprzez oczy" (Nowakowska-Kempna 1995: 167). Poprzez analogię możemy skonstatować, iż przez usta wyraża się jego aspekt fizyczny, cielesny. I tak jak oczy konceptualizowane są w wymiarze wzroku, tak usta ewokują wymiar smaku, wydobywając ich sensualny, zmysłowy charakter. Stąd dysonans zawarty między oczami a ustami symbolizuje rozdźwięk między miłością idealną - Agape, a mi- 
łością zmysłową - Eros: Bungo ujrzał tuż przy swojej twarzy przerażone oczy i rozwarte usta pani Akne i nagle, w tej samej chwili uczut, [...], że ja kocha do obłędu (Witkacy: 165); oczy miała spuszczone z wyrazem jakiegoś niezmiernego oddania się, a usta, lekko uśmiechnięte, z takomie wysunięta dolna warga, oblizywała delikatnie końcem języka. I po raz pierwszy doznał Bungo w stosunku do niej dalekiego przeczucia strasznego, nieznanego mu dotąd pożadania (Witkacy: 115-116); Nagle oczy jej staty się skośne, niedostępne i złe, a przy tym lubieżne i kuszace, i popatrzyła mu sie prosto w twarz. Usta jej miały wyraz pogardy, a jednocześnie zdawały się wyzywać do jakichś potwornych pocałunków (Witkacy: 148). Potwierdza to sama kategoryzacja pojęcia miłości w języku. „MIŁOŚĆ - jak konstatuje I. Nowakowska-Kempna - konceptualizowana jest $\mathrm{w}$ postaci CENNEGO TOWARU, jej OBIEKT to BÓSTWO, którego PIĘKNO JEST SIŁĄ FIZYCZNA, a SYMPATIA reakcją na TĘ SIŁĘ. PRZEDMIOTY MIŁOŚCI i NIENAWIŚCI postrzegane są w postaci POKARMU, w MIŁOŚCI $\rightarrow$ czegoś APETYCZNEGO, SŁODKIEGO, czego JEDZENIE przynosi ROZKOSZ i CO jest ROZKOSZĄ [...]. MIŁOŚĆ włącza model SEKSULANY w kategoriach JEDZENIA, gdyż przedmiotem POŻĄDANIA seksualnego jest JEDZENIE, a OBIEKT miłości "takomym kaskiem" (Nowakowska-Kempna, 1995: 240). Stąd usta bohaterki od samego początku zdradzają czysto erotyczny charakter: oczy miała spuszczone z wyrazem jakiegoś niezmiernego oddania się, a usta, lekko uśmiechnięte, z łakomie wysunięta dolna warga, oblizywała delikatnie końcem (Witkacy: 116); ciągle widział jej wciagające jakby w jakaś tajemnicza przepaść oczy i zagadkowy, bestialski, a święty uśmieszek jej ust (Witkacy: 129-130); oczy były martwe, nieodgadnione. Tylko koło ust błakał się ledwie dostrzegalny w mroku zły, niepokojący uśmieszek. (Witkacy: 138); ciagnace nieprzeparcie zielone oczy, i różowy jak u kota język, oblizujący bezwstydnie miękkie, gorace usta (Witkacy: 163); Jej skośne oczy patrzyły zimno i uważnie, podczas gdy usta, uśmiechnięte lubieżnie, oblizywała końcem języka (Witkacy: 164).

Także same oczy bohaterki z czasem ujawniają tę sprzeczność. Bowiem gdy w oczach zauroczonego kochanka widać zachwyt, uwielbienie i bezgraniczne oddanie, to w spojrzeniu damy jego serca kryje się pewna ambiwalencja postaw i uczuć: Czasem była w jej spojrzeniu nieziemska świętość, a czasem zielone jej oczy mówiły, że zdolna jest do rzeczy najstraszniejszych, stokroć gorszych od tych, o które oskarżały ja miejskie gadaniny (Witkacy: 101). Raz jest ono czyste i święte: Ale ten wyraz podnosit tylko jeszcze bardziej czystość i świętość jej spojrzenia i zdawało się, że Akne okupiła jakaś okrutna asceza prawo pojmowania najgłębszych tajemnic Bytu (Witkacy: 91); innym 
razem przebija przez nie złowrogość, wręcz diabelskość: wzniesione do góry jej oczy stały się skośne i błysnęty tak złowrogo, że Bungo uczuł jakiś tajemniczy lęk przed ich niezbadana głębia (Witkacy: 126). W każdym jednak przypadku spojrzenie to jest tajemnicze, zagadkowe, niezgłębione: jej wielkie obłąane swa własna dziwnościa oczy (Witkacy: 115); ciemne plamy jej oczu, które robity teraz wrażenie jakichś niezmierzonych, tajemniczych głębi. (Witkacy: 140); ciagle widziat jej wciagające jakby w jakaśs tajemnicza przepaść oczy (Witkacy: 130). Jednakże, wbrew oczekiwaniom i projekcjom spragnionego głębokiego uczucia mężczyzny, te czarowne, acz nieodgadnione oczy, kryją w sobie jedynie wewnętrzną pustkę: Czasem czuję, że jesteś ode mnie starsza nie wiekiem, ale doświadczeniem. Ale potem znowu byłaś młoda i piękna i podobałaś mi się wściekle. Nie ma mowy, żebym się Toba znudził tak prędko. Czuję w Tobie strasznie marny intelekt $i$ te powierzchowna zdolność powtarzania rzeczy styszanych lub czytanych. Poza tym tak potworna trupia pustka, że zimno się robi, kiedy się głębiej w Ciebie zajrzy (Witkacy: 284). Tajemnicą spojrzenia kobiety bowiem jest to, co Sartre nazywa „rzucaniem czaru" - umiejętność ukazywania swej cielesnej piękności. Dlatego też mężczyzna - rycerz, wchodząc w obszar widzenia swojej wybranki serca - skazany jest na przegraną w tej nierównej walce: Widział ją z dotykalna wyrazistościq, czuł niesamowity, do utraty zmysłów doprowadzający zapach jej ciała, co w połaczeniu ze wspomnieniem dotknięcia jej ust uśmiechajacych się bezwstydnie i spojrzenia jej oczu przewrotnej dziewczynki doprowadzało go do stanu zupetnie obałwaniającego pożądania. [...]. I to było najokropniejsze, że właśnie w tym poddaniu się wszystkim tym uczuciom znajdował jakaśs dzika, niezrozumiała rozkosz (Witkacy: 161). Umiejętne wykorzystywanie atutów swej urody przez kobietę sprawia, iż jedyną rolą, która pozostaje mężczyźnie jest rola bałwana: Ładny byłby ze mnie rycerz, i to jeszcze takiej jak ona kobiety. - wyznaje Bungo - [...]. Podoba mi się teraz więcej niż przedtem $i$ zaraz chciałbym doprowadzić do przemian wewnętrznych i innego życia. [...]. A co do niej, to pewno wszystko było złudzeniem i przypadkowym zbiegiem okoliczności. Ona sama nie wie, jak na kogo patrzy i do kogo robi oko i au fond jest jej wszystko jedno. Tylu takich panów jak ja musiała widzieć, ile dni uptynęło od jej urodzenia (Witkacy: 103).

\section{BIBLIOGRAFIA}

Bańko M. (red.), 2000, Inny słownik języka polskiego PWN, Warszawa.

Bartmiński J., 2009, Językowe podstawy obrazu świata, Lublin. 
Böhme G., 1998, Antropologia filozoficzna. Ujęcie pragmatyczne, przeł. Domański P., Warszawa.

Dubisz S. (red.), 2006, Uniwersalny słownik języka polskiego, Warszawa.

Luhmann N., 2003, Semantyka miłości. O kodowaniu intymności, Warszawa.

Nowakowska-Kempna I., 1995, Konceptualizacja uczuć w języku polskim, Warszawa.

Ossowska M., 1986, Ethos rycerski i jego odmiany, Warszawa.

Starczewska K., 1975, Wzory miłości w kulturze Zachodu, Warszawa.

Tokarski R., 1999, Językowy obraz świata w metaforach potocznych, [w:] Językowy obraz świata, pod red. Bartmińskiego J., Lublin.

Wierzbicka A., 1971, Kocha, lubi, szanuje. Medytacje semantyczne, Warszawa.

Witkiewicz S. I., 2007, 622 upadki Bunga czyli demoniczna kobieta, Kraków.

Wysocka A., 2009, O miłości uskładanej ze słów, Lublin.

\section{ABOUT LADIES, KNIGHTS AND “DUMMIES". THE SEMANTICS OF A “GLANCE” IN THE NOVEL “622 UPADKI BUNGA" BY WITKACY}

\section{Summary}

The article is a linguistic analysis of the realization of a paragon of chivalrous love in the novel "622 upadki Bunga" (622 Downfalls of Bungo) by Witkacy. The collected linguistic material is focused on the semantics of a "glance" being a determinant of the paragon of love, which is conceptualized on the level of the text. Its purpose is to show a way in which the author uses this cultural and linguistic paragon of love, which has consolidated in the Western culture, thus creating a linguistic image of a woman on the lexical and semantic level of the work. 